\title{
EFFECT OF SOIL MOISTURE STRESS ON UPTAKE AND RECOVERY OF TAGGED NITROGEN BY WHEAT
}

\author{
E. A. PAUL and R. J. K. MYERS \\ Department of Soil Science, University of Saskatchewan, Saskatoon, \\ Saskatchewan. Saskatchewan Institute of Pedology No. R45, received \\ July 13, 1970, accepted September 25, 1970.
}

\begin{abstract}
Labelled ${ }^{15} \mathrm{NH}_{4} \mathrm{NO}_{3}$ was used in a growth chamber to study the effect of moisture stress on the utilization of nitrogen by wheat. This made it possible to determine the recovery of nitrogen $(\mathrm{N})$ in the soil-plant system of two Chernozemic soils. Moisture stress effects were less evident in a clay soil than in a loam. Approximately $55 \%$ of the $\mathrm{N}$ utilized by the growing plants came from organic soil-N mineralized during the growing period. From 59 to $71 \%$ of the initial fertilizer plus soil mineral-N was utilized by the plants.

to $17 \%$ was lost. Losses were greatest in soils exposed to high moisture stress and were related to the residual $\mathrm{NO}_{3}-\mathrm{N}$ levels in the soil. They were attributed to denitrification. Immobilization of $\mathrm{N}$ was highest at low moisture stress where plant growth was the greatest, but mineralization was unaffected by the moisture stress applied. It was estimated that 5.0 to $6.2 \mathrm{~kg} \mathrm{~N}$ were required to produce $100 \mathrm{~kg}$ of wheat, the highest efficiency of $\mathrm{N}$ utilization being obtained at low soil moisture stress.
\end{abstract} Twenty to $36 \%$ remained in the soil, and 1

\section{INTRODUCTION}

In soils deficient in nitrogen but supplied with the other nutrient elements, fertilizer nitrogen, soil moisture and temperature interact in governing the yield and quality of wheat. Under these conditions, especially in medium-textured soils, the soil moisture level greatly influences plant and grain yields while nitrogen fertilizer has the greatest effect on protein content and sedimentation value $(5,11)$. Temperature and light intensity play their major role in determining plant characteristics such as the weight of vegetative and root materials, and kernel weight (3).

An important interacting factor in dryland cropping is soil texture. Crops on heavier-textured soils are more drought tolerant $(7,10)$. The environmental effects on the plant itself are modified by the influence of both soil moisture and the growing plant on nitrogen transformations in the soil (8). Moisture affects nitrogen nutrition through its influence on nitrogen uptake, on mineralization of organic nitrogen, and on nitrogen losses such as denitrification or volatilization. The final distribution of added $\mathrm{N}$ throughout the plant and the soil's mineral- $\mathrm{N}$, organic- $\mathrm{N}$ system are, thus, markedly affected by the soil moisture regime.

This paper describes growth chamber experiments in which the effect of moisture stress on yield and $\mathrm{N}$ uptake by wheat were measured. The relative utilization of soil and fertilizer- $\mathrm{N}$, the immobilization of fertilizer- $\mathrm{N}$ and the loss of nitrogen from the system were studied using ${ }^{15} \mathrm{~N}$-labelled fertilizer. The laboratory data were then compared with results from field experiments.

\section{MATERIALS AND METHODS}

\section{Materials and growth chamber techniques}

Two Black Chernozemic soils were used, Oxbow loam and Melfort clay. The experiments were performed in glazed ceramic pots containing the equivalent of $2 \mathrm{~kg}$ oven-dry soil. Soil moisture properties and growth techniques have been reported previously (4). The initial $\mathrm{NO}_{3}-\mathrm{N}$ levels were $32 \mu \mathrm{g} / \mathrm{g}$ for the loam soil

${ }^{1}$ Present address: C.S.I.R.O., P.O. Box 21, Katherine, N.T. 5870, Australia.

Can. J. Soil Sci. 51: 37-43 (Feb, 1971) 
and $39 \mu \mathrm{g} / \mathrm{g}$ for the clay. Total nitrogen contents were 0.28 and $0.51 \%$, respectively.

Thatcher wheat was planted at four seeds per pot, $1.3 \mathrm{~cm}$ below the surface. After six days, the two weakest plants were removed.

Ammonium phosphate $\left(\mathrm{NH}_{4} \mathrm{H}_{2} \mathrm{PO}_{4}\right)$ was applied to supply $56 \mathrm{~kg} \mathrm{P}_{2} \mathrm{O}_{5} / \mathrm{ha}$, and the level of the $\mathrm{NO}_{3}-\mathrm{N}$ already present in the soil plus fertilizer-N was adjusted to $100 \mu \mathrm{g} \mathrm{N} / \mathrm{g}$ soil. All fertilizer was added in solution with the seed. The ammonium radical of the $\mathrm{NH}_{4} \mathrm{NO}_{3}$ was labelled at an enrichment of 3.21 atom percent excess.

Three moisture treatments were applied: (a) low moisture stress, 0.3 to $1.00 \mathrm{~atm},(b)$ moderate moisture stress, 0.3 to $4.00 \mathrm{~atm}$, and $(c)$ high moisture stress, 0.3 to $10.0 \mathrm{~atm}$. All treatments were replicated four times and were maintained at low moisture stress for the first 21 days to allow uniform initial growth. The pots were weighed daily, and rotated around the tables at each weighing. The experiments were performed in a growth chamber at $18 \mathrm{C}$ for the first six weeks and at $21 \mathrm{C}$ thereafter. Water was added whenever the total pot weight indicated that the moisture level was close to the lower limit.

\section{Preparation and analysis of samples}

At maturity, the plants were removed at ground level. Grain was separated by hand and chaff was included with the straw. The entire soil mass was removed and the roots were separated by dry sieving. The plant material and soil samples were ground for total- $\mathrm{N}$ and isotope-ratio analyses.

Total-N was determined on soil, straw, grain and root samples, by the method of Bremner (1), to include nitrates. Soil nitrates were extracted with water, concentrated under vacuum, and determined by the steam distillation procedure with Devarda's alloy (2). Distillates from total-N and nitrate-N analyses were concentrated and analyzed for ${ }^{15} \mathrm{~N}$ using an Atlas GD 150 mass spectrometer. Mass spectrometer analyses were conducted on the grain only. The ${ }^{15} \mathrm{~N}$ content of the straw and roots was assumed to be the same as that of the grain.

\section{Yield}

\section{RESULTS}

In Melfort clay, the moisture stress treatments had no significant effect on yield of grain, although straw production was reduced (Table 1). In the coarsertextured Oxbow loam, moisture stress treatments governed yield, the high-stress

Table 1. The effect of moisture on yield and water usage of wheat in loam and clay soils

\begin{tabular}{cccccc}
\hline \hline \multirow{2}{*}{ Soil } & $\begin{array}{c}\text { Moisture } \\
\text { stress (atm) }\end{array}$ & Grain & Straw & Roots & $\begin{array}{c}\text { Total water use } \\
\text { (kg/pot) } \\
\text { (June 21-Sept. 30) }\end{array}$ \\
\cline { 2 - 5 } Oxbow loam & $0.3-1$ & $6.0 a$ & $11.2 a$ & $1.1 a$ & $12.65 a$ \\
& $0.3-4$ & $4.7 c$ & $8.0 b c$ & $0.7 b$ & $8.30 c$ \\
Melfort clay & $0.3-10$ & $3.6 \mathrm{~d}$ & $6.0 c$ & $0.6 b$ & $6.31 d$ \\
& $0.3-1$ & $5.1 b$ & $10.3 a b$ & $0.8 a b$ & $12.22 a$ \\
& $0.3-4$ & $5.6 a b$ & $9.9 a b$ & $1.2 a$ & $10.47 b$ \\
& $0.3-10$ & $5.4 a b$ & $7.0 c$ & $0.5 b$ & $9.01 c$ \\
\hline
\end{tabular}

*Values followed by the same letter are not significantly different at the $5 \%$ level. 
Table 2. The effect of moisture stress on $\mathrm{N}$ content of plant parts

\begin{tabular}{|c|c|c|c|c|}
\hline \multirow[b]{2}{*}{ Soil } & \multirow{2}{*}{$\begin{array}{l}\text { Moisture treatment } \\
\text { (atm) }\end{array}$} & \multicolumn{3}{|c|}{$\mathrm{N}$ content $(\mathrm{meq} \mathrm{N} / \mathrm{g})^{*}$} \\
\hline & & Grain & Straw & Roots \\
\hline Oxbow loam & $\begin{array}{r}1.0 \\
4.0 \\
10.0\end{array}$ & $\begin{array}{l}2.38 a \\
2.38 a \\
2.58 a\end{array}$ & $\begin{array}{l}0.78 c \\
1.01 a b \\
1.17 a\end{array}$ & $\begin{array}{l}0.58 a \\
0.84 a \\
0.85 a\end{array}$ \\
\hline Melfort clay & $\begin{array}{r}1.0 \\
4.0 \\
10.0\end{array}$ & $\begin{array}{l}2.34 a \\
2.29 a \\
2.45 a\end{array}$ & $\begin{array}{l}0.88 b c \\
0.83 b c \\
1.01 a b\end{array}$ & $\begin{array}{l}1.00 a \\
0.93 a \\
0.80 a\end{array}$ \\
\hline
\end{tabular}

*Values followed by the same letter are not significantly different at the $5 \%$ level.

( 0 to $10 \mathrm{~atm}$ ) treatment producing $40 \%$ less grain and straw than the low-stress ( 0 to $1.0 \mathrm{~atm}$ ) treatment. This effect was related to total water use. In the Oxbow soil, water use was depressed by $50 \%$ in the high-stress treatments compared with a depression of only $25 \%$ in the Melfort soil. The relative proportion of grain, straw and root yields were consistent throughout the treatments in the Oxbow soil. In Melfort, the 4-atm moisture stress treatment had a high proportion of roots relative to grain and straw, and the 10 -atm treatment had a high proportion of grain.

\section{Nitrogen uptake}

The moisture stress treatments used had little effect on nitrogen concentration in straw, grain and roots (Table 2). Total-N uptake followed a similar pattern to yield. Increased moisture stress depressed $\mathrm{N}$ uptake in the loam soil but had no obvious effect in the clay (Table 3 ), except for a possible slight depression of straw-N. An average of $58 \%$ of the plant-N was present in the grain, with the balance present in straw and roots. Coarse root material recoverable by sieving comprised $5.6 \%$ of the total plant weight, but contained only $3.2 \%$ of the plant-N.

Approximately $55 \%$ of the plant-N was derived from mineralization of soil organic-N during the experiment, while only $45 \%$ was derived from the mineral-N in the soil (fertilizer- $N$ plus soil mineral-N) present at the beginning of the experiment. The relative use of fertilizer- $\mathrm{N}$ is further indicated by the atom percent excess of ${ }^{15} \mathrm{~N}$ in the soil mineral-N samples analyzed. At the end of the growth

Table 3. The effect of moisture stress on $\mathrm{N}$ uptake of wheat in loam and clay soils

\begin{tabular}{ccccccc}
\hline $\begin{array}{c}\text { Treatment } \\
(\mathrm{atm})\end{array}$ & Grain & Straw & Roots & Total & $\begin{array}{c}\text { Plant N from } \\
\text { soil ON* } \\
\text { (mg N/pot) }\end{array}$ & $\begin{array}{c}\text { Plant N from } \\
\text { initial mineral- } \\
\text { N }(\%)\end{array}$ \\
\cline { 3 - 5 } $\begin{array}{c}\text { Oxbow loam } \\
0.3-1\end{array}$ & 202 & 126 & 9 & 337 & 188 & \\
$0.3-4$ & 156 & 114 & 8 & 278 & 147 & 44.2 \\
$0.3-10$ & 132 & 99 & 7 & 238 & 116 & 47.1 \\
Melfort clay & & & & & & \\
$0.3-1$ & 165 & 127 & 11 & 303 & 179 & 41.3 \\
$0.3-4$ & 168 & 115 & 16 & 299 & 173 & 41.9 \\
$0.3-10$ & 175 & 99 & 6 & 280 & 157 & 44.0 \\
\hline
\end{tabular}

*OM $=$ organic matter. 
Table 4. The amount of $\mathrm{N}$ required to produce $100 \mathrm{~kg}$ grain under various moisture stress treatments

\begin{tabular}{lcc}
\hline Soil & Treatment (atm) & $\mathrm{kg} \mathrm{N} / 100 \mathrm{~kg}$ grain \\
\hline Oxbow loam & $0.3-1.0$ & 5.0 \\
& $0.3-4.0$ & 5.6 \\
Melfort clay & $0.3-10.0$ & 6.2 \\
& $0.3-1.0$ & 5.2 \\
& $0.3-4.0$ & 5.4 \\
\hline
\end{tabular}

period, the ${ }^{15} \mathrm{~N}$ enrichment of the $\mathrm{NO}_{s}-\mathrm{N}$ in the loam soil was only $60 \%$ of that in the plant materials. However, in the clay soil, which had only a small amount of $\mathrm{NO}_{3}-\mathrm{N}$ at the conclusion of the experiment, the ${ }^{15} \mathrm{~N}$ enrichment approximated $30 \%$ that of the plants. This indicated that the major part of the $\mathrm{NO}_{3}-\mathrm{N}$ found at the conclusion of the growth period was mineralized soil-N rather than unused mineral- $\mathrm{N}$ from the beginning of the growth period.

\section{Conversion of mineral- $N$ to grain- $N$}

For practical purposes, it is important to know the amount of $\mathrm{N}$ required to produce a given quantity of grain. Considering the plant-N and the $\mathrm{N}$ lost to be the $\mathrm{N}$ "used" in producing grain, an efficiency figure can be calculated (Table 4). A range of $5.0-6.2 \mathrm{~kg} \mathrm{~N}$ was required to produce $100 \mathrm{~kg}$ wheat. The greatest efficiency occurred under low moisture stress conditions where $\mathrm{N}$ losses were small and where $\mathrm{N}$ mineralization was more rapid. These results could apply to certain field conditions where the grain- $\mathrm{N}$ constitutes $60 \%$ of total uptake and where $\mathrm{N}$ losses are small.

\section{Nitrogen distribution in the soil-plant system}

On the basis of ${ }^{15} \mathrm{~N}$ values for recovery in the plant and in the soil, the nitrogen distribution in the various components of the soil-plant system was calculated (Table 5). Of the mineral-N initially present, 59-71\% was removed by the wheat plants and $20-36 \%$ remained in the soil, while $1-17 \%$ was unaccounted for. Losses were insignificant at the low and moderate moisture stress treatments in the loam soil. The greatest losses occurred on the high-stress (low-moisture) treatments on both soils, the clay soil losing $17 \%$ of the initial mineral-N. In

Table 5. Nitrogen distribution of ${ }^{15} \mathrm{~N}$-labelled mineral $\mathrm{N}$ applied to Oxbow loam and Melfort clay under three moisture stress treatments

\begin{tabular}{cccccc}
\hline & & \multicolumn{3}{c}{ Recovery of labelled N (mg/pot) } \\
\cline { 3 - 5 } Soil & Treatment (atm) & Plant N & $\begin{array}{c}\text { Soil } \\
\text { org-N }\end{array}$ & $\begin{array}{c}\text { Soil } \\
\text { min-N }\end{array}$ & Total \\
\hline Oxbow loam & $0.3-1$ & 141 & 53 & 4 & 198 \\
& $0.3-4$ & 138 & 42 & 19 & 199 \\
Melfort clay & $0.3-10$ & 117 & 31 & 36 & 184 \\
& $0.3-1$ & 120 & 64 & 7 & 191 \\
& $0.3-4$ & 137 & 40 & 10 & 187 \\
\hline
\end{tabular}

*Total labelled $\mathrm{N}=200 \mathrm{mg} /$ pot. 
the loam soil, the magnitude of loss appeared to be related to the residual $\mathrm{NO}_{3}-\mathrm{N}$ levels, and, thus, was inversely related to the amount that had been removed from the available-N pool by plant uptake or immobilization. It is likely that the losses were due to denitrification of excess nitrate.

The use of labelled fertilizer makes it feasible to assess the contribution of soil organic and mineral- $\mathrm{N}$ to plant uptake and to determine the cycling of $\mathrm{N}$ in the soil. In the growth chamber experiment, the assumption was made that the initial soil and fertilizer nitrate- $\mathrm{N}$ behaved similarly to the added ammonium- $\mathrm{N}$ in relation to crop uptake and losses. The unlabelled portion of plant- $\mathrm{N}$ is assumed to be the product of mineralization of soil organic- $\mathrm{N}$ during the growth period. Increased availability of water resulted in an enhanced content of soil organic- $N$ in the plant; the soil- $\mathrm{N}$ accounted for slightly more than half of the total- $\mathrm{N}$ taken up by the plants. Results from plant analysis only would indicate that increased mineralization of soil organic matter occurred at the higher moisture treatment. However, the possibility that soil- $\mathrm{N}$ accumulates in the nitrate- $\mathrm{N}$ and is not utilized by the plants must be taken into account.

Calculations indicate (Table 6) that if both the plant-N plus the soil nitrate-N are taken into account, there is no difference in mineralization due to stress treatments. It is of further interest that the two soils are fairly similar in their overall mineralization rates, the finer-textured, higher organic matter soil contributing slightly more $\mathrm{N}$.

Moisture stress, however, did have an effect on immobilization of the labelled mineral-N, as indicated by the recovery of labelled- $\mathrm{N}$ in the soil organic matter (Table 5). In this case, there was a definite effect attributable to moisture in both soils; the higher mositure treatment resulted in the higher immobilization of $\mathrm{N}$. This occurred in the clay soil, even though there was no significant difference relative to the effect of moisture on plant growth.

\section{DISCUSSION}

The use of labelled fertilizer made it feasible to separate the relative contribution of mineralized soil organic-N, and fertilizer plus initial $\mathrm{NO}_{3}-\mathrm{N}$ to plant growth. The soil organic-N mineralized during the period of crop growth supplied slightly more than half the total available-N. The data support the concept of an internal cycle of $\mathrm{N}$ in the soil (6), with simultaneous mineralization and immobilization. The quantity of soil organic- $\mathrm{N}$ mineralized during the growth period was constant over the range of moisture stress treatments. In contrast, increasing moisture

Table 6. Organic nitrogen mineralized during the growth chamber experiment

\begin{tabular}{ccccc}
\hline Soil & Treatment (atm) & $\begin{array}{c}\text { Plant N derived } \\
\text { from soil OM } \\
(\mathrm{mg} \mathrm{N} / \mathrm{pot})\end{array}$ & $\begin{array}{c}\text { Soil NO } \text {-N de- } \\
\text { rived from OM } \\
(\mathrm{mg} \mathrm{N} / \mathrm{pot})\end{array}$ & $\begin{array}{c}\text { Mineralization } \\
\text { (mg N/pot) }\end{array}$ \\
\hline Oxbow loam & $0.3-1$ & 188 & $10^{*}$ & 198 \\
Melfort clay & $0.3-4$ & 147 & 47 & 194 \\
& $0.3-10$ & 116 & 75 & 212 \\
& $0.3-1$ & 179 & 48 & 221 \\
\hline
\end{tabular}

*Based on percent excess ${ }^{15} \mathrm{~N}$ in other treatments. 
stress markedly inhibited the immobilization of labelled mineral-N. The magnitude of immobilization was only one-seventh to one-third that of mineralization.

Nitrogen losses from the soil-plant system are usually associated with high moisture conditions (denitrification) or with soil drying (ammonia volatilization). The initial three-week period of this experiment, during which adequate moisture levels were maintained, would rule out ammonia losses. As losses were extremely small in some treatments, significant $\mathrm{N}$ loss during this stage obviously did not occur. When the different moisture treatments were applied, highest losses were observed where drying was more severe. This could suggest a drying-rewetting effect, and also reflects nitrate availability. This means that denitrification occurred when nitrate was present, that is, when plant uptake and immobilization did not remove all the available nitrate. Where soil moisture was maintained within a narrower range close to field capacity, plant uptake of $\mathrm{N}$ and immobilization were both increased, and soil nitrate quickly declined to low levels such that denitrification did not occur.

The nitrogen distribution during and after a two-year field experiment using ${ }^{15} \mathrm{~N}$-labelled materials has recently been described by Myers and Paul (9). A nitrogen balance sheet for the field experiments indicates that where moisture stress limited crop growth, such as in the Bradwell sandy loam, the uptake of fertilizer-N by the plant was very low $(20-30 \%)$. However, much of the mineral-N did not remain as soil nitrate within the rooting zone; approximately $35 \%$ of the fertilizer- $\mathrm{N}$ was lost during a period encompassing two growing seasons plus the intervening spring and fall periods. Wheat grown on the heavier-textured Sutherland clay soil proved more drought tolerant, resulting in higher uptake of fertilizer- $\mathrm{N}$ by the plant and, consequently, lower losses (16-24\%). The use of microplots in the field has, therefore, shown similar results to those found in the growth chamber, that is, labelled-N losses were closely related to the amount of nitrate- $\mathrm{N}$ available. The two fine-textured soils behaved similarly in the growth chamber and in the field: $\mathrm{N}$ losses, immobilization, yield and $\mathrm{N}$ uptake were all of the same order of magnitude. However, in two coarser textured soils, differences were observed in that yield and $\mathrm{N}$ uptake were poorer, and $\mathrm{N}$ losses were higher in the field experiment. Immobilization was unaffected. The growth chamber stress treatments were apparently not severe enough to equal the field conditions in the case of the coarser textured soils. These data indicate the relevance of field and growth chamber data and point to the need for analyses of all the plant and soil components in $\mathrm{N}$ turnover and balance studies.

\section{ACKNOWLEDGEMENTS}

This study was made possible by the availability of funds from the National Research Council and National Grain Company. The authors gratefully acknowledge the technical assistance of L. Johns in the mass spectrometer determination.

\section{REFERENCES}

1. BREMNER, J. M. 1965. Total nitrogen, p. 1149-1178 in C. A. Black et al. (ed.), Methods of soil analysis. Part 2. Chemical and microbiological properties. Amer. Soc. Agron., Madison, Wis.

2. BREMNER, J. M. 1965. Inorganic forms of nitrogen, p. 1179-1237 in C. A. Black et al. (ed.), Methods of soil analysis. Part 2. Chemical and microbiological properties. Amer. Soc. Agron., Madison, Wis. 
3. CAMPBELL, C. A. and READ, D. W. L. 1968. Influence of air temperature, light intensity and soil moisture on the growth, yield and some growth analysis characteristics of Chinook wheat grown in the growth chamber. Can. J. Plant Sci. 48: 299-311.

4. HUTCHEON, W. L. and PAUL, E. A. 1966. Control of the protein content of Thatcher wheat by nitrogen fertilization and moisture stress. Can. J. Soil Sci. 46: 101-108.

5. HUTCHEON, W. L. and RENNIE, D. A. 1960. The relationship of soil moisture stress and nutrient availability to the growth characteristics and quality of wheat. Trans. 7th Int. Congr. Soil Sci. 3: 488-495.

6. JANSSON, S. L. 1958. Tracer studies on nitrogen transformations in soil with special attention to mineralization-immobilization relationships. K. LantbrHogsk. Ann. 24: 101-361.

7. LEHANE, J. J. and STAPLE, W. J. 1965. Influence of soil texture, depth of soil moisture storage, and rainfall distribution on wheat yields in southwestern Saskatchewan. Can. J. Soil Sci. 45: 207-218.

8. MATE, F. and LATKOVICS, I. 1966. Study of the utilization of various nitrogen chemical fertilizers with ${ }^{15} \mathrm{~N}$ stable isotope labelling. Agrochem. Soil Sci. 15: 75-84.

9. MYERS, R. J. K. and PAUL, E. A. 1971. Plant uptake and immobilization of ${ }^{{ }^{15} \mathrm{~N}}$ labelled ammonium nitrate in a field experiment with wheat. In Proc. FAO/IAEA Meet. on recent developments in the use of ${ }^{15} \mathrm{~N}$ in soil-plant studies. (In press).

10. PRIMOST, von E. 1962. Die Abhangigkeit des Kornertrages, Klebergehaltes und der Quellzahl des Weizens von Stickstoffdungung und Bodenart. Plant and Soil 24: 94-107.

11. SOSULSKI, F. W., LIN, M. and PAUL, E. A. 1966. Effect of moisture, temperature and nitrogen on yield and protein quality of Thatcher wheat. Can. J. Plant Sci. 46: 583-588. 